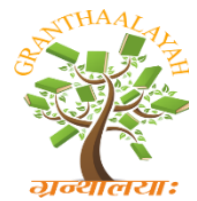

INTERNATIONAL JOURNAL OF RESEARCH GRANTHAALAYAH A knowledge Repository

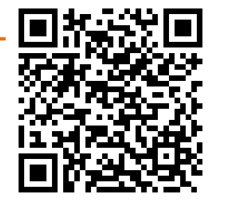

Science

\title{
PROTEOLITIC BACTERIA CULTURE OF ISOLATION RESULTS IN ORGAN LIVING OF FISHING GROUPER CULTURE RESULTS
}

\author{
Kasprijo $^{* 1}$, Sri Manarni ${ }^{2}$ \\ ${ }^{* 1,2}$ Faculty of Fisheries and Marine Sciences, Jenderal Soedirman University, Purwokerto, \\ Indonesia
}

\begin{abstract}
The grouper is a sea water fish that is often cultivated. But in digesting feeds is often not optimal. To improve feed efficiency, one effort that can be done is to know the activity of proteolytic bacteria in milkfish digestion. The purpose of this study was to determine the presence and activity of proteolytic bacteria. The method used is the observation method with a purposive sampling technique. The abundance of bacteria in the digestive tract is calculated by the TPC (Total Plate Count) method. Based on the research results, it is known that there are proteolytic bacteria in the digestion group which are indicated by the presence of a clear zone around the bacterial colony that is grown on specific media (skim milk). There is also the activity of proteolytic bacteria in the digestion grouper by measuring the hydrolyzed clear zone with an average in the anterior part of the intestine $2.3 \mathrm{~mm}$, middle $2.6 \mathrm{~mm}$, posterior $2.65 \mathrm{~mm}$. The results of this study indicate that the bacteria bacillus sp with sorbitol media, molasses and nutrient broth with a storage time of 40 days at $40 \mathrm{C}$ did not experience a decrease in bacterial density that was significantly different.
\end{abstract}

Keywords: Grouper; Bakteria Isolate; Digestive Tract; Proteolitic Bacteria; Viability.

Cite This Article: Kasprijo, and Sri Manarni. (2019). "PROTEOLITIC BACTERIA CULTURE OF ISOLATION RESULTS IN ORGAN LIVING OF FISHING GROUPER CULTURE RESULTS." International Journal of Research - Granthaalayah, 7(11), 266-275. https://doi.org/10.29121/granthaalayah.v7.i11.2020.366.

\section{Introduction}

The digestion system in fish is simpler than land animals, so the digestive mechanism or digestibility of feed is very limited. Limitations to the availability of digestive enzymes, high levels of nutrient feed formulations are not balanced by the ability of fish to digest and absorb available nutrients (protein). The ability to digest in fish that is not optimal causes the feed given will be secreted in a condition where nutrients are still high. In addition, some feed ingredients come from vegetable sources, and have complex bonds that make it difficult for protein and phosphate compounds to undergo degradation, as a result the high phosphate content is wasted in the culture medium ${ }^{[12]}$. 
Enzymes are biological catalysts in chemical reactions that are needed in life. Enzymes are proteins that are synthesized in cells and excreted from producing cells through the process of exocytosis. The enzymes that are secreted out are used for digestion outside the cell (inside the digestive cavity) or called extracellular digestion, while the enzymes that are retained inside the cell are used for digestion inside the cell itself called intracellular digestion ${ }^{[2]}$. Digestive enzymes that are secreted in the digestive cavity come from the cells of the gastric mucosa, the cervical pyloric, the pancreas, and the intestinal mucosa. Therefore, the development of the digestive system is closely related to the development of enzyme activity in the cavity of the digestive tract ${ }^{[28]}$. These enzymes act as catalysts in the hydrolysis of proteins, fats, and carbohydrates into simple ingredients. Based on Haryati's research (2002), there is a link between digestive enzyme activity and the development of digestive organ structure and food habits of milkfish. Decreased activity of the protease enzyme is thought to be due to a change in eating habits, from carnivores to omnivores. It was also found that the activity of trypsin, pepsin, lipase, and amylase enzymes increased with increasing age and body size.

Digestive enzyme activity is a good indicator to determine digestive capacity. The ability of fish to digest a type of food depends on the physical and chemical factors of food, the type of food, the age of the fish, the physical chemistry of water, and the number of digestive enzymes in the digestive system. Carbohydrase, protease, and lipase enzymes affect the digestion of food in the anterior intestine. Protease is an enzyme that plays a role in protein hydrolysis ${ }^{[3]}$.

One effort to maximize the digestibility of feed, which can be done is to know the presence of microflora originating from the digestive tract that has proteolytic activity (digesting protein). The microflora will regulate the microbial environment in the intestine, inhibit intestinal pathogenic microorganisms and improve feed efficiency by releasing enzymes that help the digestive process ${ }^{[12]}$. In maximizing the digestibility of feed in groupers can be carried out screening of proteolytic bacteria that exist in the digestion of groupers.

One of the bacteria that is proteolytic is the Bacillus species. Bacillus in its application in aquaculture can increase the average weight of tiger shrimp maintenance by adding to shrimp feed, Bacillus is a rod-shaped bacterium, classified as gram-positive, motile, aerobic, positive catalase and varying oxidation states ${ }^{[3]}$.

Bacteria that are beneficial for digestion have great potential as probiotics because of their superiority compared to other bacteria. The beneficial properties of bacteria in the form of probiotics are that it can be used to support improved health. These bacteria act as normal flora in the digestive system ${ }^{[8]}$.

\section{Material and Methods}

\subsection{Research Material}

\subsubsection{Object}

The object used in this study was grouper, measuring 15-20 cm and weighing 30-50 g 


\subsubsection{Tool}

The tools used for research are surgical scissors, tweezers, measuring cups, becker glass, petri dishes, glass objects, microscopes, erlenmeyers, dropper pipettes, measuring pipettes, incubators, scales, bunsen fires, matches, cameras, stationery, tisue, micropipets , tips, tubes, pastele pellets, autoclaves, microwaves, ose needles, vortex, aluminum foil, plastic wraping, trays, containers, and aerators.

\subsubsection{Material}

The materials used for this research are $\mathrm{NaCl} 0.9 \%$, methylated spirits, salt, distilled water, skim milk, MRS Agar, TSA (Trypticase Soy Agar), crystal violet (gram A), lugol (gram B), acetone alcohol (gram C), safranin (gram D), sorbitol, nutrient broth, and molasses

\subsection{Research Methods}

The method used in this study uses the observation method with a purposive sampling technique. The main variable is observing the activity of proteolytic bacteria, and an additional variable is observing the activity and viability of the Research Procedure

\subsubsection{Preparation of Tools and Materials}

The tool is cleaned and sterilized using an autoclave for 20 minutes, while the material is autoclaved for 15 minutes.

\subsubsection{Making Bacteria Culture Media}

- TSA Media (Trypticase Soya Agar)

TSA media were made by means of every $20 \mathrm{~g}$ TSA powder mixed with $0.25 \mathrm{~g} / 100 \mathrm{~mL}$ salt poured into an erlenmeyer then $500 \mathrm{ml}$ of distilled water was added. TSA solution is heated using an electric stove until it boils. TSA is sterilized using an autoclave at $121 \mathrm{oC}$ for 15 minutes. Then the TSA solution is kept until slightly warm until later it is used for further treatment.

- $\quad$ Skim Milk Media

TSA media were made by means of every $20 \mathrm{~g}$ TSA powder mixed with $0.25 \mathrm{~g} / 100 \mathrm{~mL}$ salt then mixed with $2 \%$ skim milk which was roasted for 2 hours, then poured into erlenmeyer then added $500 \mathrm{~mL}$ of distilled water. TSA solution is heated using an electric stove until it boils. TSA is sterilized using an autoclave at $1210 \mathrm{C}$ for 15 minutes. Then the TSA solution is kept until slightly warm until later it is used for further treatment.

\subsubsection{Sampling}

Intake of grouper digestive tract contents is done by removing the digestive organs (intestine) from the adult phase of the fish that have been killed. The digestive organs are measured in length. The intestine is divided into three parts, namely the front, middle, and back which are cultured separately. 


\subsubsection{Bacterial Isolation}

The intestine was smoothed with pastele pellets, added $1 \mathrm{~mL}$ of sterile physiological solution $(\mathrm{NaCl} 0.9 \%)$ and homogenized using vortex. Samples that have been vortexed are taken $0.5 \mathrm{~mL}$ to be diluted in a sterile $0.9 \% \mathrm{NaCl}$ solution in a $10-1$ tube then homogenized with a vortex taken $0.5 \mathrm{~mL}$ is diluted again in a 10-2 dilution tube and re-homogenized. This process is carried out until a 10-5 dilution of $0.1 \mathrm{~mL}$ of sample from 10-2 to 10-4 dilution is cultured by the pour plate method on TSA media. Then it was re-cultured on a petri dish containing TSA, selective media (skim milk), Lactobacillus MRS Agar and Bacillus Agar. Then incubated at a temperature of $28.5^{\circ} \mathrm{C}$ for $18-24$ hours for bacteria to grow ${ }^{[9]}$. Calculation of bacterial abundance is calculated using the formula of bacterial abundance ${ }^{[4]}$. Counting the number of bacteria using the TPC (total plate count) method. A cup that produces $30-300$ colonies is selected and counted ${ }^{[29]}$.

Bacterial abundance $=\Sigma$ colony $\times \frac{1}{\text { dilution }} \times \frac{1}{\text { planted volume }(m l)} \times \frac{1}{\text { sample weight }(g)}(\mathrm{CFU} / \mathrm{g})$

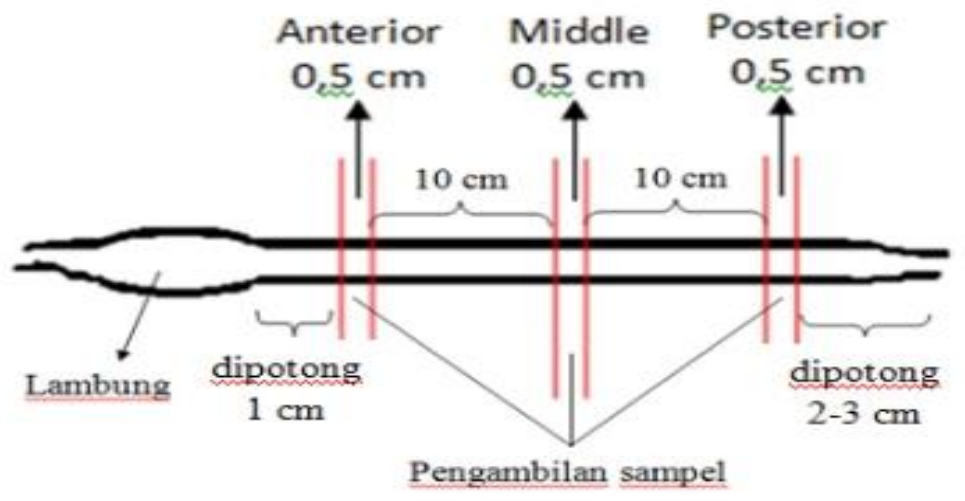

Figure1: Digestive Schema taken ${ }^{[15]}$

\subsubsection{Observation of Proteolytic Bacterial Activity}

The agar culture media containing casein, ie skim milk, were poured into a petri dish. The isolate to be tested was inoculated into the media so that by inoculating as much as one eye ose culture in the middle of the cup, then spread about $0.5 \mathrm{~cm}$. Furthermore, it was incubated at $28.5^{\circ} \mathrm{C}$ for 24 hours. If the casein hydrolysis process occurs, you will see a clear area around the microbial colony, otherwise if there is no hydrolysis, the area around the colony remains turbid. Based on the data obtained, it can be determined the value of protease ratio with the formula used Sumardi (2010) is as follows:

Rasio AP $=\frac{\mathrm{dt}}{d 0}$

Information

$\mathrm{AP}=$ proteolytic activity $(\mathrm{mm})$

$\mathrm{dt}=$ total diameter of the hydrolysis zone (clear zone) $(\mathrm{mm})$

$\mathrm{d} 0=$ bacterial colony diameter $(\mathrm{mm})$ 


\subsubsection{Observation of Bacterial Morphology}

Observation of bacterial morphology of the shape, elevation, color, and type of bacterial colonies that grow on the media.

\subsubsection{Gram Staining}

Staining the characteristics of gram bacteria is carried out on glass objects, glass objects are removed first with alcohol and passed several times on a bunsen flame. Then the bacterial isolate is taken with an aseptic needle and smeared on a glass object. Bacterial isolates were then dropped into violet crystals (grams A) and left for 1 minute, then processed with running water and aerated to dry. The bacterial isolate was then dropped again with an iodine solution (gram B) and left for 1 minute, then collected with running water and aerated to dry. Furthermore, bacterial isolates were dropped with $90 \%$ alcohol (gram C) for 30 seconds, then watered and aerated to dry. The bacterial isolate was then dropped with safranin (gram D) for 30 seconds and removed with water, dried with suction paper and dried with air, then traced using a microscope. Gram-positive bacteria are marked with a purple color which indicates that the bacteria bind to the color of violet crystals, while gram-negative bacteria are characterized by pink which indicates the bacteria are unable to bind to the color of violet crystals ${ }^{[24]}$. Data collection

Data collection was carried out after observation of proteolytic bacterial activity, observation of morphological bacteria, gram-positive and negative tests and calculation of the amount of bacterial density. From the observations, the data obtained is then presented in the form of tables and charts provided with existing references.

\section{Results and Discussions}

\subsection{Bacteria Abundance in Milkfish Digestion Channel}

Calculation of bacterial abundance in the digestion tract of groupers using the Total Plate Count (TPC) method. The samples used were the anterior, middle, and posterior bowels each $3 \mathrm{~cm}$ long. The results of the calculation of bacterial abundance in groupers can be seen in Table 1. and Figure1.

Table1: Bacterial Abundance in Grouper Digestive Tract

\begin{tabular}{|l|c|c|c|}
\hline \multirow{2}{*}{ Sample } & \multicolumn{3}{|c|}{ Total bacteria } \\
\cline { 2 - 4 } & Anterior & Middle & Posterior \\
\hline 1 & $1,1 \times 10^{5}$ & $17,2 \times 10^{5}$ & $20,2 \times 10^{5}$ \\
\hline 2 & $15,5 \times 10^{5}$ & $94,62 \times 10^{5}$ & $101,5 \times 10^{5}$ \\
\hline Average & $8,3 \times 10^{5}$ & $55,91 \times 10^{5}$ & $60,85 \times 10^{5}$ \\
\hline
\end{tabular}

Bacteria that enter the intestine are influenced by the feed given and the environment, namely water and pond substrates. The composition of bacteria in the digestive tract of fish is also influenced by substances that are dissolved in the maintenance media so that the abundance of bacteria in the intestines of fish is higher. Abundance of Bacteria in the Digestive Tract of Groupers [24]. 
The abundance of bacteria in the digestive tract of groupers is higher in the back or posterior intestine. Calculation results obtained with an average of $8.3 \times 105$, in the anterior section, $55.91 \mathrm{x}$ 105 in the middle, and the highest $60.85 \times 105$, namely in the posterior

\subsection{The Existence and Activity of Proteolytic Bacteria in The Grouper Digestive Tract}

The presence of proteolytic bacteria is characterized by the formation of a hydrolysis clear zone around a bacterial colony that is planted on skimmed agar media. Based on research results, bacteria that have clear zones around their colonies are capable of hydrolyzing casein contained in milk, which means that these isolates have protease activity that is able to break down proteins into amino acids ${ }^{[11]}$.

The results of the study explained that there were proteolytic bacteria in milkfish 1 in the anterior part, namely 1 isolate, in the middle, which was 6 isolates, in the posterior that was 1 isolate. 2 anterior grouper fish, there are 2 isolates, in the middle is 1 isolate, and in the posterior is 2 isolates. While in the anterior part of the water sample there are 5 isolates, in the middle which is 4 isolates, in the posterior which is 6 isolates, and on the substrate, there are 7 isolates. This explains the activity of proteolytic bacteria in the digestive tract of milkfish causing the absorption of nutrients or nutrients to protein to be better, so that the energy produced is able to meet the needs of fish to grow, move, and make the immune system run optimally to maintain its survival ${ }^{[12]}$.

Table2: Activity Proteolitik bacteria

\begin{tabular}{|l|c|c|c|}
\hline \multirow{2}{*}{ Sample } & \multicolumn{3}{|c|}{ Activity Proteolitik Bacteria (mm) } \\
\cline { 2 - 4 } & Anterior & Middle & Posterior \\
\hline kerapu 1 & 2 & 2,7 & 2,8 \\
\hline kerapu 2 & 2,6 & 2,5 & 2,5 \\
\hline average & 0,23 & 0,26 & 2,65 \\
\hline & Inlet & Middle & Outlet \\
\hline water & 3,7 & 2,5 & 4,5 \\
\hline Substrat & \multicolumn{4}{|c}{1,9} \\
\hline
\end{tabular}

Proteolytic bacteria are bacteria that catalyze total hydrolysis of proteins into amino acids. The activity of proteolytic bacteria has a positive effect on digesting food in the digestion of groupers because bacterial activity in the intestines of fish maximizes the absorption of nutrients in fish digestion ${ }^{[21]}$. Casein is a protein found in milk. Milk protein is also like other proteins composed of amino acids. This amino acid can be used by certain bacteria as a source of carbon and energy [13]. Bacteria that can hydrolyze proteins are bacteria that produce extracellular proteinase enzymes. All bacteria have a proteinase enzyme in the cell but not all have an extracellular proteinase enzyme. During protein fermentation hydrolyzed into its derivatives, such as proteases, peptons, peptides, and amino acids ${ }^{[29]}$.

Casein is a macromolecule that consists of amino acid subunits which are connected by peptide bonds $(\mathrm{CO}-\mathrm{NH})$. When milk is mixed with bacterial media, casein in milk will cause the media to become turbid. This turbidity is caused by casein reacting with $\mathrm{Ca} 2+$ ions to form $\mathrm{Ca}$-casein. This complex does not dissolve in the media but form colloidal bonds, so the media looks turbid. If the organism has an extracellular proteinase enzyme that hydrolyses casein, then the area around the 
colony looks clear. This clarity is caused by the casein molecule described, while microorganisms that do not have proteolytic then the surrounding colonies will remain turbid.

The results in Table 2. explain that the milkfish, water and substrate samples have proteolytic bacterial activity which is characterized by the presence of a clear zone around the bacterial colony, with an average in the anterior intestine of $3 \mathrm{~mm}$, in the middle of $2.6 \mathrm{~mm}$, in posterior $2.6 \mathrm{~mm}$, whereas in water the inlet is $3.7 \mathrm{~mm}$, middle $2.5 \mathrm{~mm}, 4.5 \mathrm{~mm}$ outlet and the substrate is $1.9 \mathrm{~mm}$. This means that these isolates have proteolytic bacterial activity. The presence of proteolytic bacteria in milkfish digestion indicates the breakdown of proteins (essential and non-essential amino acids) into simpler components that can be surrendered by the body ${ }^{[13]}$

\subsection{Proportion of Bacillus Sp. and Lactobacillus Sp.}

Bacillus sp. is a beneficial bacterium for protease production because it is non-pathogenic and well explored to produce various types of proteases ${ }^{[27]}$.
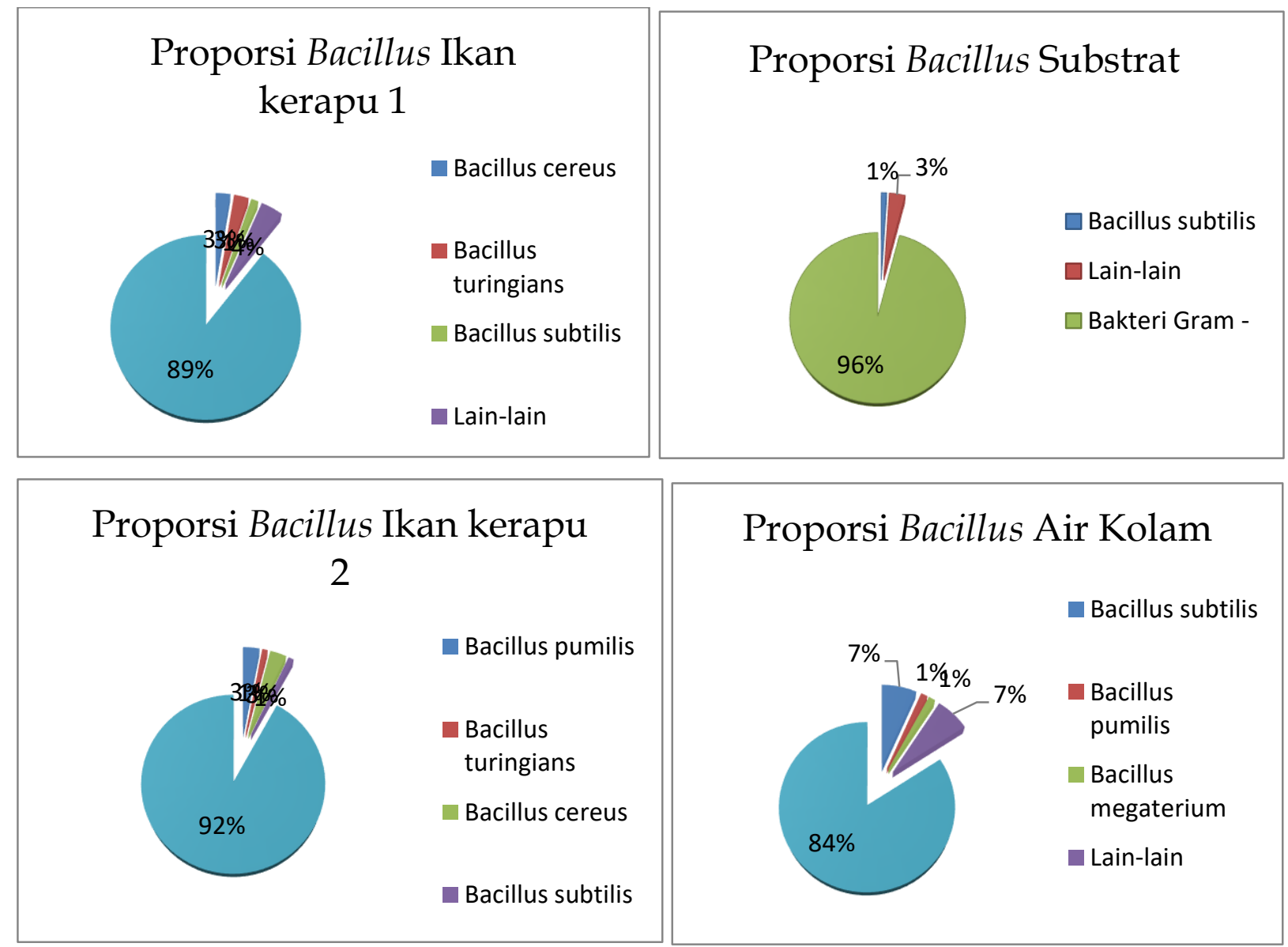

\section{Proporsi Bacillus Air Kolam}

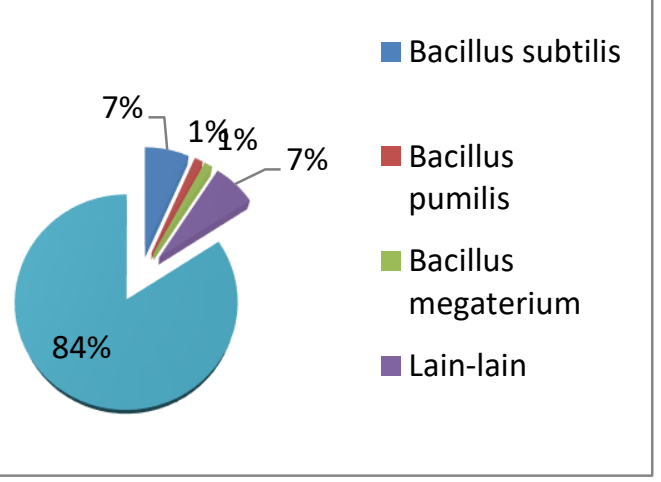

Figure 2. Proportion of Lactobacillus sp.

Bacteria genus Lactobacillus sp. it has morphological characteristics as follows: the color of the colony is milky white or slightly creamy, the shape of the colony is round with edges like wool. 
The cells are rod-shaped and are usually fixed, measuring 0.5-1.2 x 1.0-10.0 $\mu \mathrm{m}$. They are usually long rods but sometimes almost round, usually in the form of short chains, Gram positive, not motile, positive oxidase, negative catalase, positive methyl red, optimum at temperatures of 30$370 \mathrm{C}$ and grow well at 3-7\% NaCl. Lactobacillus sp. Bacteria. these include Gram +, nonporpora, not motile by peritrichous flagella, facultative anaerobes, sometimes microaerophilic, slightly grown in air but good under low oxygen pressure, and some anaerobes in isolation ${ }^{[5]}$.

Characteristics of the bacterium genus Lactobacillus sp. from the digestive tract of milkfish that has been done, which is a round, white, gram-positive, negative catalase and stem-shaped cell form. These results are in line with the statement of Suciati (2016), which states that Lactobacillus sp has a round white / milky white colony shape, convex elevation, gram positive, and stem-shaped cells.

In the percentage between bacteria Lactobacillus sp. not more than the bacteria Bacillus sp. that is because according to Nursyirwani (2011) Lactobacillus sp. not dominant in the normal intestinal microbiota of larvae, but several studies have shown the existence of a digestive tract of fish.

\subsection{Gram Staining}

This gram staining aims to determine the microscopic characteristics of each bacterial strain, both the reaction and shape. This gram staining uses four types of solution, namely crystal violet (gram A), lugol iodine (gram B), alcohol (gram C), and safranin (gram D) (the principle of gram coloring is the ability of cell walls to bind to basic dyes (crystals violet) after washing with $96 \%$ alcohol. This relates to the composition of the cell wall constituent compounds, ie in gram-positive bacteria contain more pepdodligan than gram-negative ${ }^{[18]}$.

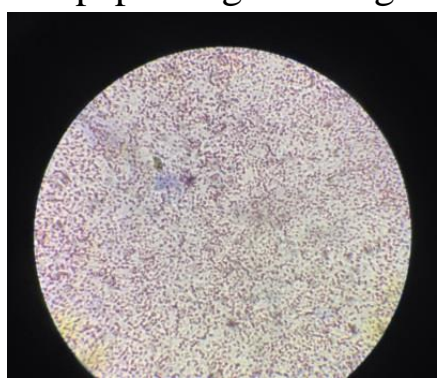

$[\mathrm{A}]$

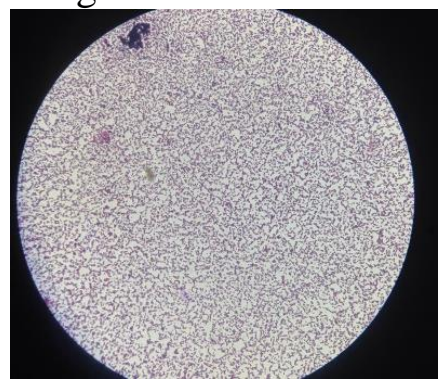

[B]

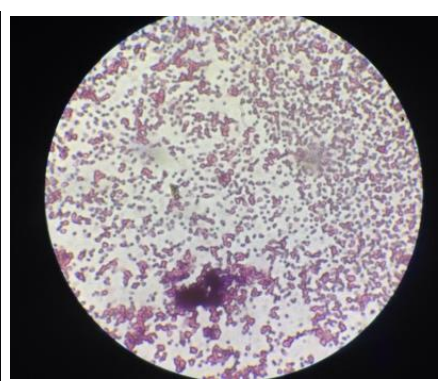

[C]

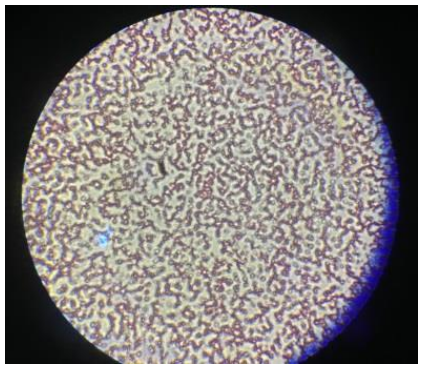

[D]

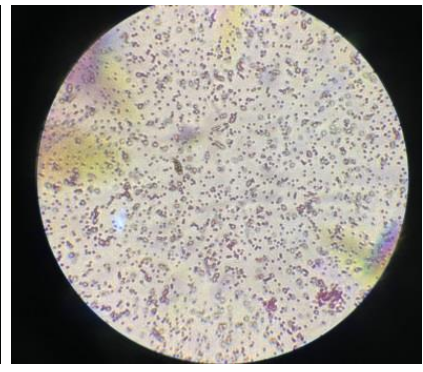

[E]

Figure3: Gram Staining Results 
Note: [A] water inlet; [B] substrate; [C] water outlet; [D] grouper 1; [E] grouper 2.

Figure 3. Explain that the results of gram staining in pictures $[A],[B],[D]$ are gram negative because after passing the gram staining process produces a pink color. Whereas in the picture [C] produces a purple color, it indicates that the sample from one of the outlet water isolates is gram positive. According to Hadioetomo (1985) gram-positive bacteria appear purple larena ribonucleic acids in the cytoplasm of gram-positive cells have a higher lipid content and are generally easily soluble from alcohol which enlarges the pores of the cell wall, thus in gram cells negative faster.

\section{Conclusions and Recommendation}

Based on the research conducted it can be concluded that:

- There are proteolytic bacteria in the digestion of groupers which is indicated by the presence of a clear zone around the bacterial colony that is grown on specific media (skim milk)

- There is proteolytic bacterial activity in grouper digestion by measuring hydrolyzed clear zones with an average in the anterior part of the intestine $2.3 \mathrm{~mm}$, middle $2.6 \mathrm{~mm}$, posterior $2.65 \mathrm{~mm}$ while in the inlet water that is $3.7 \mathrm{~mm}$, middle $2.5 \mathrm{~mm}, 4.5 \mathrm{~mm}$ outlet and on the substrate that is $1.9 \mathrm{~mm}$.

\section{References}

[1] Abadi, A.F. 2009. Pengaruh pemberian suplemen pakan yang mengandung Bacillus sp. dalam pakan buatan terhadap laju pertumbuhan benih ikan nila. Fakultas Perikanan dan Ilmu Kelautan. Universitas Padjadjaran, Bandung, $41 \mathrm{hlm}$.

[2] Affandi, R., Sjafei, D.S., Raharjo, M.F., Sulistiono. 2005. Fisiologi Ikan Pencernaan dan Penyerapan Makanan. Laporan penelitian. Institut Pertanian Bogor.

[3] Alamsyah, S. 2006. Penggunaan Mikroflora Saluran pencernaan Sebagai Probiotik untuk Meningkatkan Pertumbuhan dan kelangsungan Hidup Ikan Bandeng (Chanos chanos Forsskal). Laporan Penelitian. Institut Pertanian Bogor, Bogor. 42 hal.

[4] Damongilala, L. 2009. Kadar Air Dan Total Bakteri Pada Ikan Roa (Hemirhampus Sp) Asap Dengan Metode Pencucian Bahan Baku Berbeda. Jurnal Ilmiah Sains. 9(2): 191-198.

[5] Feliatra., E. Irwan., S. Edwar. 2004. Isolasi dan identifikasi Bakteri probiotik dari Ikan kerapu Macan (Ephinephelus fuscogatus) dalam Upaya Efisiensi pakan. Jurnal Natur Indonesia. 6(2): 7580.

[6] Fuller, R. 1992. History and Development of Probiotics. The scientific Basis. Chapman and Hall, New York, p. 1-8.

[7] Hadioetomo, R.S. 1985. Mikrobiologi Dasar Dalam Praktd Teknik dan Prosedur Dasar Laboratorium. Jakarta: Penerbit Gramedia.

[8] Hardianingsih, Riani, Rostiati Nonta Refina Napitupulu, Titin Yulinery, 2006. Isolasi dan Uji Resistensi Beberapa Isolat Lactobacillus pada pH Rendah. Jurusan Biologi FMIPA UNS Surakarta. Biodiversitas. 7(1): 15-17.

[9] Irmawati, Y. dan Jane, L. D. 2014. Bakteri pada Saluran Pencernaan Ikan Nila (Oreochromis niloticus) Jurnal Ilmiah dan Agribisnis dan Perikanan. 7(2).

[10] Ivanovska, Tanja Petreska, dkk. 2012. Microencapsulation of Lactobacillus casei in chitosan-caalginate microparticles using spray-drying method. Macedonian Journal of Chemistry and Chemical and Chemical Engineering. 31(1): 115-123. 
[11] Kaiser, C., Merwe, R.V. D., Bekker, T. F., Labuschange, N., 2005. In-vitro Inhibition of Mycelial Growth of Several Phytopathogenic Fungi, Including Phytophthora cinnsmomi by Soluble Silicon. South African Avocado Growers Association Yearbook. 28 70-74.

[12] Kurniasih, T., Lusiastuti, A. M., Azwa, Z. I., Melati, I. 2014. Isolasi dan Seleksi Bakteri Saluran Pencernaan Ikan lele sebagai Upaya Mendapatkan Kandidat Probiotik untuk Efisiensi Pakan Ikan. Jurnal Akuakultur. 9(1): 99-109.

[13] Lay, B.W. 1994. Analisis Mikroba di Laboratorium. Jakarta: PT. Raja Grafindo Persada.

[14] Murtidjo, B. A. 2002. Seri Budidaya Bandeng Tuntunan bagi Petambak dan Peminat Budidaya Bandeng Intensif. Penerbit Kanisius. Yogyakarta. 84 hal.

[15] Mutoifah. 2017. Jumlah Total bakteri pada Saluran Pencernaan Gurami (Osphronemus gouramy) yang Diberi Pakan Azolla microphylla dan pellet dengan Perbandingan Berbeda. Skripsi. Fakultas Perikanan dan Ilmu Kelautan Universitas Jenderal Soedirman Purwokerto.

[16] Nursyirwani., W. Asmara., A.E.T.H. Wahyuni., Triyanto. 2011. Isolasi Bakteri Asam Laktat dari Usus Ikan Kerapu Macan (Epinephelus fuscoguttatus) dan Potensinya Sebagai Antivibrio. Jurnal Ilmu Kelautan. 16(2): 70-77.

[17] Pelczar, M.J., Chan. E.C.S. 1986. Dasar-dasar Mikrobiologi I. Hadioetomo, Katna S, Imas T, Tjitrosono, S.S., Angka, S.L, penerjemah. Jakarta: Universitas Indonesia.

[18] Prabaningtyas, S. 2003. Karakteristik Bakteri Koleksi Laboratorium Mikrobiologi Universitas Negeri Malang. Malang: Chimera Vol: VIII. No.2.

[19] Puspitasari, F. D., Shovitri, M., Kuswytasari, N. D. 2012. Isolasi dan Karakterisasi Bakteri Aerob Proteolitik dari Tangki Septik. Jurnal Sains dan Seni ITS. 1(1).

[20] Ray, A. K., K. Ghosh., E. Ringo. 2012. Enzime Producing Bacteria Isolated from Fish Gut: A Review. Aquaculture Nutrition. 18(465-492).

[21] Saanin, H. 1984. Taksonomi dan Kunci Identifikasi Ikan, Jilid I-II. Edisi II. Bina Cipta. Bogor.

[22] Safani, E. E., Wanodya, A. C. K., Alfiyan, L., Erlix, R. P. 2019. Potensi Ekstrak Daun Bandotan (Ageratum conyzoides L.) Sebagai Spray untuk Pemulihan Luka Mencit Diabetik yang Terinfeksi Staphylococcus aureus. Biotropic, 3(1): 68-78.

[23] Safrida, Y. D., C. Yulvizar, C. Nanda D. 2012. Isolasi dan Karakterisasi Bakteri Berpotensi Probiotik pada Ikan Kembung (Rastrelliger sp.). Jurusan Biologi FMIPA. 1(3): 200-203.

[24] Saparinto, C. Purnomowati, I., Hidayati, D. 2006. Bandeng Berduri Lunak. Penerbit Kanisisus. Yogyakarta. 11 hal.

[25] Sumardi, Christina Nugroho., Dwi Haryani. 2010. Isolasi Bacillus Penghasil Selulase dari Saluran Pencernaan Ayam Kampung. J Sains MIPA. 16 (1). 62-68.

[26] Tennalli, G., B, Udapudi., P, Naik. 2012. Isolation of Proteolytic Bacteria and Characterization of their Proteolytic Activity. International Journal of Advances in Engineering, Science and Technology (IJAEST). 2(3).

[27] Walford, J.T. dan Lam, T.J. 1993. Development of Digestive Tract and Proteolitic Enzyme Activity in Seabass (Lates calcarifer) Larvae and Juveniles. Journal Aquaculture. 109: 187-205.

[28] Winarno, F.G., Fardiaz, S. 1980. Pengantar Teknologi Pangan. Jakarta: Grarnedia

[29] Yunita, M., Yusuf, H., Rini, Y. 2015. Analisis Kuantitatif Mikrobiologi pada Makanan Penerbangan (Aerofood ACS) Garuda Indonesia Berdasarkan TPC (Total Plate Count) dengan Metode Pour Plate. Jurnal Keteknikan Pertanian Tropis dan Biosistem, 3(3): 237-248

\footnotetext{
*Corresponding author.

E-mail address: kaspriyo37@yahoo.com
} 